\title{
PENGEMBANGAN PERANGKAT PEMBELAJARAN SISTEM PERSAMAAN LINEAR DUA VARIABEL DENGAN MODEL PROBLEM BASED LEARNING
}

\author{
Rosalinda Paulina Lainata ${ }^{1}$, I Wayan Damai ${ }^{2}$, Anekke Pesik ${ }^{3}$ \\ ${ }^{1,2,3}$ Prodi S2 Pendidikan Matematika, PPs, Universitas Negeri Manado \\ Jalan Raya Tondano, Koya, Tondano Sel., Kabupaten Minahasa, Sulawesi Utara, Indonesia

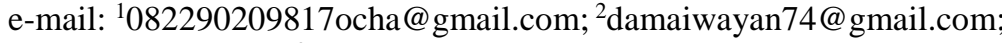 \\ 3pesikanekke123@gmail.com; \\ Submitted: November 27, 2020 \\ Revised: January 21, 2021 \\ Accepted: January 26, 2021 \\ corresponding author*
}

\begin{abstract}
Abstrak
Penelitian ini bertujuan untuk menghasilkan perangkat pembelajaran sistem persamaan linear dua variabel dengan menggunakan model Problem Based Learning yang memenuhi kriteria valid, praktis dan efektif. Penelitian ini dikategorikan sebagai penelitian pengembangan. Penelitian ini menggunakan model ADDIE yang dikembangkan oleh Dick and Carey. Tahapnya ada lima tahap yaitu: 1) Analysis, 2) Design, 3) Development, 4) Implementation, dan 5) Evaluation. Perangkat pembelajaran yang dihasilkan dalam penelitian adalah rencana pelaksanaan pembelajaran (RPP), lembar kegiatan peserta didik (LKPD) dan evaluasi hasil belajar (EHB). Hasil penelitian menyatakan bahwa produk yang dikembangkan memenuhi kriteria valid, praktis, dan efektif. Perangkat pembelajaran layak digunakan dengan skor rata-rata penilaian perangkat pembelajaran dari validator sebesar 3,5 dengan kriteria valid. Kepraktisan perangkat pembelajaran dilihat dari angket respon siswa yang memberikan respon yang positif dan kemampuan guru mengelola pembelajaran pada pertemuan pertama dengan rata-rata 3,69 dan pertemuan kedua 3,46 yang mencapai kategori baik, yaitu terletak pada interval $3,50 \leq T K G<4,50$. Keefektifan perangkat pembelajaran dilihat dari tes hasil belajar siswa yang menunjukkan nilai ketuntasan belajar siswa dengan rata-rata $80 \%$
\end{abstract}

Kata Kunci: pengembangan perangkat pembelajaran, problem based learning, sistem persamaan linear dua variabel

\section{DEVELOPMENT OF LEARNING TOOLS FOR TWO VARIABLE LINEAR EQUATION SYSTEMS WITH PROBLEM BASED LEARNING MODEL}

\begin{abstract}
This study aims to produce a two-variable linear equation system learning tool using the Problem Based Learning model that meets the criteria of being valid, practical and effective. This research is categorized as development research. This study uses the ADDIE model developed by Dick and Carey. There are five stages, namely: 1) Analysis, 2) Design, 3) Development, 4) Implementation, and 5) Evaluation. The learning tools produced in the study were the lesson plan (RPP), student activity sheets (LKPD) and evaluation of learning outcomes (EHB). The results showed that the products developed to meet the criteria of validity, practicality, and effectiveness. The learning device is feasible to use with an average score of the learning device assessment from the validate of 3.5 with valid criteria. The practicality of the learning device was seen from the student response questionnaire which gave a positive response and the teacher's ability to manage learning at the first meeting with an average of 3.69 and the second meeting of 3.46 which reached the good category, which was located in the interval $3.50 \leq \mathrm{TKG}<4,50$. The effectiveness of the learning device is seen from the test of student learning outcomes which shows the value of student learning completeness by an average of $80 \%$.
\end{abstract}

Keywords: learning tool development, problem based learning, a system of two variable linear equation

\section{Pendahuluan}

Perangkat pembelajaran dapat memberikan kemudahan bagi siswa untuk belajar. Perangkat pembelajaran yang dimaksud meliputi Rencana
Pelaksanaan Pembelajaran (RPP), Lembar Kegiatan Peserta Didik (LKPD), dan Evaluasi Hasil Belajar (EHB). Materi sistem persamaan linear dua variabel (SPLDV) merupakan bagian 
dari materi Aljabar yang dipelajari pada kelas VIII semester genap dalam kurikulum 2013.

Materi tersebut merupakan materi yang sangat erat hubungannya dalam kehidupan seharihari, dikarenakan banyak hal-hal yang ditemui menggunakan prinsip SPLDV seperti menghitung harga suatu barang pada saat berbelanja, di mana kita hanya mengetahui total belanja beberapa barang tanpa tahu pasti harga satuan barang yang dibeli. Materi SPLDV memiliki beberapa kegiatan dalam pembelajarannya, diantaranya: membuat bentuk PLDV, membuat model masalah dari PLDV, membuat model masalah dari SPLDV, dan menuliskan penyelesaian masalah yang berkaitan dengan SPLDV dalam kehidupan sehari-hari.

Siswa dengan kemampuan tinggi sudah mampu mengubah soal kontekstual ke dalam bentuk atau model matematika sehingga mereka dapat menyelesaikan soal-soal kontekstual sampai tuntas, namun tidak dengan siswa yang kemampuan sedang dan siswa dengan kemampuan mudah, mereka masih kesulitan memahami soal kontekstual atau soal cerita untuk di ubah ke dalam model matematika. Ini disebabkan oleh kurangnya latihan siswa dalam menyelesaikan masalah yang membutuhkan pemodelan matematika.

Hal ini menjadi keputusasaan, kebosanan, dan kurang maksimalnya perkembangan potensi dalam menyelesaikan soal-soal berbasis masalah. Sehingga kebanyakan siswa hanya bisa menyelesaikan soal-soal yang persis sama seperti contoh yang diberikan guru. Namun ketika diberikan soal-soal kontekstual lain yang sedikit berbeda baik dalam latihan, ulangan atau ujian siswa tersebut tidak mampu memahami soal untuk diubah ke dalam model atau bentuk matematika dikarenakan mereka hanya menghafal konsepkonsep yang diberikan oleh guru tetapi tidak memahami konsep tersebut.(Puspitasari, dkk)

Berdasarkan hasil tes awal untuk mengukur kemampuan pemodelan matematika yang dilakukan oleh peneliti diperoleh data dari 10 siswa yaitu 3 siswa mampu memahami masalah, 1 siswa mampu membangun model matematika dengan menggunakan model nyata, 1 siswa mampu menjawab pertanyaan matematika dengan menggunakan model matematika yang dibentuk, 2 siswa mampu menginterpretasikan hasil matematika yang diperoleh di dunia nyata, 1 siswa mampu memvalidasi solusi, dan 2 siswa lainnya tidak mampu menyelesaikan masalah.

Dari data tersebut dapat dilihat bahwa kemampuan pemodelan matematika siswa kelas VIII masih sangat rendah. Adapun perbaikan yang dapat dilakukan adalah dengan menerapkan model- model pembelajaran yang dapat meningkatkan kemampuan pemodelan matematika siswa. Banyaknya teori dan hasil penelitian para ahli pendidikan yang menunjukkan bahwa pembelajaran akan berhasil apabila peserta didik dapat berpartisipasi aktif dalam proses pembelajaran. Slameto (2006) mengemukakan bahwa pembelajaran adalah suatu usaha untuk membuat siswa belajar sehingga situasi tersebut merupakan peristiwa belajar yaitu usaha untuk terjadinya tingkah laku dari siswa. Mulyasa (2005) menambahkan bahwa pembelajaran adalah proses interaksi antara peserta didik dengan lingkungan sehingga terjadi perubahan perilaku kearah yang lebih baik

Pembelajaran yang ada hubungannya dengan lingkungan maupun kehidupan siswa, sehingga membuat siswa dapat mengingat tentang pembelajaran tersebut. Salah satu model yang dapat digunakan untuk pengembangan perangkat pembelajaran dalam menigkatkan hasil belajar siswa adalah dengan menggunakan model PBL. Karena model PBL dianggap sangat memungkinkan untuk digunakan dalam pembelajaran materi SPLDV ini.

Hal ini dapat dilihat dari salah satu karakteristik model PBL yaitu pembelajaran yang dimulai dengan masalah. Menurut Savoie dan Hughes (Wena, 2009) menyatakan bahwa strategi berbasis masalah memiliki beberapa karakteristik yaitu :

a. Belajar dimulai dengan suatu permasalahan, permasalahan yang diajukan harus berhubungan dengan dunia nyata,

b. Mengorganisasikan pembelajaran di seputar permasalahan,

c. Memberikan tanggung jawab dalam membentuk dan menjalankan proses belajar kepada siswa,

d. Menggunakan kelompok kecil,

e. Menuntut siswa untuk mendemonstrasikan apa yang dipelajari.

Oleh karena itu materi SPLDV dirasa sangat sesuai dalam penerapan model pembelajaran PBL karena di dalam PBL siswa dituntut untuk mengidentifikasi permasalahan yang ada, sehingga mereka tidak sekedar menghafal. Dengan PBL diharapkan siswa tidak kesulitan jika diberikan soal model lain bahkan yang lebih sulit sekalipun.

Perangkat pembelajaran yang digunakan akan mendukung kegiatan pembelajaran agar lebih bermakna. Perangkat pembelajaran yang dapat diterapkan dalam proses pembalajaran materi SPLDV untuk siswa kelas VIII SMP bermacammacam, di antaranya: silabus, RPP, LKPD, EHB, 
media pembelajaran, dan buku ajar siswa (Trianto, 2010). Tiap perangkat pembelajaran memiliki sifat dan fungsi yang berbeda-beda beserta kelebihan dan kekurangannya masing-masing. Namun demikian, dari beberapa perangkat pembelajaran yang ada, semua berperan dalam mencapai tujuan kegiatan pembelajaran.

Kegiatan yang sudah tersusun dan terencana dengan baik akan memaksimalkan ketercapaian tujuan kegiatan. Perangkat pembelajaran yang dapat memfasilitasi dalam penyusunan langkahlangkah pembelajaran yang sistematis adalah RPP. Trianto (2010) mengungkapkan RPP adalah panduan langkah-langkah yang akan dilakukan oleh guru dalam kegiatan pembelajaran yang disusun dalam skenario kegiatan. Artinya, RPP merupakan hal utama yang harus ada dalam semua pembelajaran yang akan dilaksanakan dan sebagai pedoman guru dalam melaksanakan pembelajaran.

Perlunya perangkat pembelajaran berupa RPP ini diperkuat oleh Peraturan Pemerintah Nomor 19 Tahun 2005 pasal 19 yang mengisyaratkan bahwa seorang guru yang hendak mengajarkan materi kepada siswa, harus memiliki strategi yang tepat dimulai dari membuat RPP. RPP dalam pembelajaran adalah hal pertama yang harus ada untuk mendukung tercapainya pembelajaran yang baik karena pembelajaran yang akan dilakukan telah dirancang sebaik-baiknya.

Dalam kegiatan perencanaan ini akan dituliskan hal-hal yang realistis untuk dilakukan siswa maupun guru. Selain itu, RPP sangat mendukung penguasaan pembelajaran dalam materi SPLDV, terutama menyelesaikan permasalahan nyata. Penyelesaian permasalahan nyata diawali dengan suatu masalah yang akan ditemukan penyelesaiannya kemudian diberikan langkah-langkah dalam penyelesaiannya. Langkah-langkah tersebut perlu ditulis secara rinci dalam suatu perencanaan beserta alokasi waktunya.

Pada observasi yang dilakukan peneliti di SMP Katolik St. Rosa De Lima Tondano diperoleh informasi bahwa guru masih kesulitan untuk mengembangkan perangkat pembelajaran yang sesuai dengan kurikulum 2013. Perangkat pembelajaran yang dimaksud adalah silabus, RPP, dan LKPD.

Menurut Permendikbud No. 22 Tahun 2016 tentang Standar Proses Pendidikan Dasar dan Menengah, silabus merupakan acuan penyusunan kerangka pembelajaran untuk setiap kajian mata pelajaran, RPP merupakan rencana kegiatan pembelajaran tatap muka untuk satu pertemuan atau lebih. Menurut Trianto (2012) LKPD adalah panduan yang digunakan siswa untuk melakukan kegiatan penyelidikan atau pemecahan masalah.

Silabus yang digunakan sekolah menggunakan silabus yang dikeluarkan oleh pemerintah, namun silabus tersebut merupakan desain minimal sehingga diharapkan guru mampu mengembangkan silabus sesuai kebutuhan. Pada RPP yang ada guru menggunakan pembelajaran langsung dengan metode ceramah dan hanya sedikit waktu untuk diskusi kelompok. Hal ini tentunya akan menjadikan pembelajaran yang berpusat pada guru dan tidak sesuai dengan kurikulum 2013, menurut kurikulum 2013 proses pembelajaran harus berpusat pada siswa dan guru sebagai fasilitator.

Menurut kurikulum 2013 proses pembelajaran harus berpusat pada siswa dan guru sebagai fasilitator. Pada materi pembelajaran tidak terlihat jelas fakta, konsep, prinsip, dan prosedur karena materi pembelajarn hanya disajikan seperti bahan ajar. Langkah-langkah pembelajaran yang terdapat pada RPP masih menggambarkan proses pembelajaran yang berpusat kepada guru, pada langkah pembelajaran telah memuat kegiatan pendahuluan, inti, dan penutup tetapi belum terlalu rinci dan tidak memperlihatkan proses keaktifan siswa. Pada penilaian hasil belajar tidak terlihat jelas penilaian pengetahuan dan penilaian keterampilan yang digunakan oleh guru.

LKPD yang digunakan hanya berisi ringkasan materi, contoh soal dan latihan yang tidak mengajak siswa menemukan konsep pembelajaran matematika, tidak meningkatkan rasa ingin tahu siswa serta tidak membuat siswa menjadi mandiri dalam menyelesaikan masalah yang disajikan karena siswa hanya membaca ringkasan materi pada LKPD, melihat contoh soal serta mengerjakan latihan. Pada soal latihan yang disajikan, tidak semua soal memuat soal kontekstual yang tidak meningkatkan proses berfikir siswa. LKPD seperti ini tidak membantu siswa dalam menyelesaikan masalah matematika yang ditemukan, karena dalam sebuah LKPD harus ada aspek yang mengukur aspek pengetahuan dan aspek keterampilan.

Diperlukan suatu penelitian yang menghasilkan perangkat pembelajaran yang sesuai dengan kurikulum sehingga dapat dijadikan pedoman dan penunjang bagi guru selama proses pembelajaran dan dapat membantu siswa dalam proses pembelajaran, meningkatkan pemahaman siswa, dan membiasakan siswa menyelesaikan permasalahan dalam kehidupan sehari-hari.

Dimana hal ini terwujud dengan merancang RPP yang berpedoman kepada silabus dan 
dilaksanakan dalam LKPD yang mengaitkan pengetahuan dengan kehidupan sehari-hari. Menurut Permendikbud Nomor 81 tahun 2013 kegiatan pembelajaran pada kurikulum 2013 menggunakan pendekatan saintifik. Pendekatan saintifik adalah pendekatan yang digunakan dalam pembelajaran yang dilakukan melalui proses ilmiah.

Apa yang dipelajari dan diperoleh siswa dilakukan dengan indra dan akal pikiran sendiri sehingga siswa mengalami secara langsung dalam proses mendapatkan ilmu pengetahuan. Hal ini diperkuat oleh Soemanto (2006) bahwa proses pengajaran dan pembelajaran matematika yang baik adalah pengajaran yang melibatkan siswa secara langsung dalam pemecahan masalah dan ikut serta dalam menemukan konsep tersebut. Salah satu model pembelajaran kurikulum 2013 yang sesuai dengan permasalahan yang telah diobservasi peneliti adalah model Problem Based Learning.

Berdasarkan kebutuhan yang telah diuraikan di atas, perangkat pembelajaran yang akan diterapkan harus sesuai dan memungkinkan untuk diterapkan pada siswa kelas VIII SMP. Dari beberapa perangkat pembelajaran, yang paling sesuai dan memungkinkan untuk membantu proses pembelajaran dalam proses penyelidikan adalah LKPD. Hal ini diperkuat oleh Trianto (2009) yang menyatakan LKPD adalah panduan siswa yang digunakan untuk melakukan kegiatan penyelidikan atau pemecahan masalah.

Hasil observasi dan analisis terhadap LKPD yang ada di SMP Katolik St. Rosa De Lima Tondano menunjukkan bahwa LKPD kurang memfasilitasi pemahaman konsep SPLDV untuk siswa. Selain itu, LKPD tersebut tidak berorientasi pada masalah. Dalam menyelesaikan soal-soal yang ada pada LKPD, siswa hanya perlu menghafal rumus yang sudah diberikan di LKPD.

Mereka tidak dituntut untuk menemukan maupun mengemukakan ide dalam penyelesaian suatu permasalahan yang akan membuat siswa tidak aktif sehingga pemikiran siswa sulit berkembang. Pada soal yang terdapat dalam LKPD pun kurang bervariasi sehingga dapat dimungkinkan siswa kurang termotivasi untuk belajar. Tampilan yang terdapat dalam LKPD kurang menarik, sehingga dapat memungkinkan kurang ketertarikan minat siswa untuk belajar.

Perangkat pembelajaran yang hendak dikembangkan harus memiliki kualitas yang baik. Menurut Nieveen (1999), mengatakan bahwa suatu produk pengembangan material kegiatan pembelajaran haruslah memenuhi kriteria valid, praktis, dan efektif. Produk tersebut harus valid agar produk sesuai terhadap cara atau ketentuan yang seharusnya. Selain valid, produk tersebut harus praktis agar dapat digunakan dengan mudah. Sedangkan produk harus efektif agar tujuan pembelajaran dapat tercapai dengan baik.

Selain menggunakan perangkat pembelajaran yang sesuai, pendekatan dalam menyampaikan materi SPLDV dalam kegiatan pembelajaran kepada siswa pun harus tepat sesuai dengan karakteristik materi SPLDV dan karakteristik siswa. Terdapat banyak pendekatan yang dapat diterapkan pada RPP dan LKPD untuk membelajarkan siswa kelas VIII SMP pada materi SPLDV.

Untuk mengukur hasil belajar digunakan EHB. Menurut Permendiknas (2016) EHB merupakan bahan untuk memperbaiki proses pembelajaran sesuai dengan Standar Penilaian Pendidikan. Dalam penyusunan evaluasi hasil belajar yang disusun oleh guru tidak diuji kevalidan dan reliabelnya.

Hasil dari penelitian ini diharapkan perangkat pembelajaran yang tercipta berupa RPP, LKPD dan EHB dapat membantu proses kegiatan pembelajaran untuk siswa kelas VIII SMP yaitu guru dimudahkan dalam penyampaian materi dan siswa dimudahkan dalam menangkap materi dalam materi SPLDV sesuai dengan standar kompetensi dan kompetensi dasar pada Kurikulum 2013 dalam mata pelajaran matematika.

\section{Metode Penelitian}

Penelitian ini merupakan penelitian pengembangan yaitu suatu penelitian untuk mengembangkan suatu produk. Produk yang dihasilkan dari penelitian ini berupa perangkat pembelajaran yang terdiri dari RPP, LKPD dan EHB dengan menggunakan model PBL pada materi SPLDV. Desain pengembangan yang digunakan dalam penelitian ini mengacu pada model ADDIE yang di kembangkan oleh Dick and Carry pada tahun 1996 yang merancang sistem pembelajaran (Endang, 2013). Model pengembangan ADDIE menggunakan lima tahap pengembangan, yaitu analysis (analisis), design (desain), development (pengembangan), implementation (implementasi), dan evaluation (evaluasi).

\section{a. Analysis}

Pada tahap ini dilakukan analisis kebutuhan perangkat pembelajaran, analisis kurikulum, dan analisis karakteristik siswa. Adapun rincian tahap analisis yaitu: a). Analisis 
kebutuhan perangkat pembelajaran, b). Analisis Kurikulum, dan c). Analisis Karakteristik Siswa.

b. Design

Pada tahap perancangan, kegiatan yang dilakukan peneliti adalah menyusun rancangan atau kerangka perangkat pembelajaran, sehingga menghasilkan prototype 0 (contoh perangkat pembelajaran).

c. Development

Tujuan tahap ini adalah untuk menghasilkan draft final perangkat pembelajaran yang baik. Kegiatan pada tahap ini adalah: validasi ahli, simulasi, dan ujicoba lapangan.

d. Implementation

Langkah nyata untuk menerapkan sistem pembelajaran yang sedang kita buat. Artinya, pada tahap ini semua yang telah dikembangkan diset sedemikian rupa sesuai dengan peran atau fungsinya agar bisa diimplementasikan.

e. Evaluation

Evaluasi yang dilakukan adalah dengan mengalisis data hasil penilaian RPP oleh dosen ahli, penilaian LKPD oleh dosen ahli dan guru, penilaian LKPD oleh siswa, penilaian observasi keterlaksanaan pembelajaran, dan hasil tes tertulis yang dilakukan oleh siswa.

\section{Hasil dan Pembahasan}

\subsection{Deskripsi Proses dan Hasil Pengembangan Perangkat Pembelajaran}

Penelitian ini bertujuan untuk menghasilkan perangkat pembelajaran matematika dengan menggunakan model pembelajaran Problem Based Learning pada materi sistem persamaan linear dua variabel di kelas VIII SMP Katolik Sta. Rosa De Lima Tondano. Perangkat pembelajaran yang dihasilkan berupa (1) RPP, (2) LKPD, dan (3) EHB. Perangkat pembelajaran ini dikembangkan berdasarkan model pengembangan ADDIE.

\subsection{Tahap Analisis (Analysis)}

Tahap analisis adalah langkah pertama dari model pengembangan ADDIE. Pada tahap ini yang dilakukan peneliti yaitu menganalisis kebutuhan perangkat pembelajaran, analisis kurikulum, dan analisis karakteristik siswa.

\section{Analisis Kebutuhan Perangkat Pembelajaran}

Analisis kebutuhan perangkat pembelajaran dilakukan dengan cara peneliti mengumpulkan informasi-informasi penting terkait dengan masalah yang terjadi dalam pembelajaran matematika siswa kelas VIII SMP Katolik Sta. Rosa De Lima Tondano. Hasil analisis ini diperoleh melalui survei dan wawancara dengan guru matematika di sekolah tersebut.

Berdasarkan hasil survei dan wawancara diperoleh informasi bahwa dalam pelaksanaan pembelajaran di kelas, guru yang lebih mendominasi dibandingkan dengan siswa. Guru masih kesulitan dalam membuat perangkat pembelajaran yang dapat memfasilitasi hal tersebut. Oleh sebab itu, perlu dilakukan suatu upaya yang dapat mengatasi permasalahanpermasalahan tersebut, yaitu dengan mengembangkan perangkat pembelajaran yang sesuai dengan materi SPLDV.

\section{Analisis Tugas}

Analisis tugas bertujuan untuk mengetahui tugas-tugas yang harus dikuasai siswa pada materi sistem persamaan linear dua variabel sesuai dengan Kurikulum 2013, maka tugas-tugas yang akan dilakukan siswa selama proses pembelajaran adalah: (a) Tugas pada sub pokok bahasan sistem persamaan linear dua variabel dalam LKPD1: (1) Menjelaskan definisi persamaan linear dua variabel, (2) Menjelaskan definisi sistem persamaan linear dua variabel, (3) Membuat model matematika yang berkaitan dengan sistem persamaan linear dua variabel, (4) Menentukan himpunan selesaian sistem persamaan linear dua variabel dengan metode grafik; dan (b) Tugas pada sub pokok bahasan Persamaan Nilai Mutlak Linear Satu Variabel dalam LKPD 2: (1) Menentukan himpunan penyelesaian sistem persamaan linear dua variabel dengan menggunakan metode subtitusi, dan (2) Menentukan himpunan penyelesaian sistem persamaan linear dua variabel dengan menggunakan metode eliminasi.

\section{Analisis Karakteristik Siswa}

Analisis karakteristik siswa bertujuan untuk mengetahui karekteristik siswa kelas VIII SMP Katolik Sta. Rosa De Lima Tondano seperti siswa yang suka bersosialisasi dengan teman-teman serta lingkungannya, siswa yang biasa saja, siswa yang menyenangkan, atau siswa yang sulit dalam penyesuaian diri dengan teman-teman dan lingkungannya.

Dari hasil analisis karakteristik siswa, didapatkan bahwa siswa kelas VIII SMP Katolik Sta. Rosa De Lima Tondano memiliki kemampuan yang beragam. Berdasarkan beberapa karakteristik siswa tersebut maka dibutuhkan suatu upaya untuk mengatasi masalah tersebut yaitu dengan mengembangkan suatu perangkat pembelajaran dengan tujuan untuk membangkitkan motivasi belajar serta keaktifan siswa dalam mengikuti setiap pembelajaran matematika di kelas. 
Oleh karena itu peneliti mengembangkan suatu perangkat pembelajaran matematika dengan menggunakan model PBL, karena dengan model ini siswa lebih aktif dalam kegiatan pembelajaran yang dapat meningkatkan kemampuan mereka dalam mengungkapkan ide-ide mereka terkait dengan materi yang mereka pelajari.

\subsection{Tahap Perancangan (Design)}

Tahap analisis adalah langkah pertama dari model pengembangan ADDIE. Pada tahap ini yang dilakukan peneliti yaitu menganalisis kebutuhan perangkat pembelajaran, analisis kurikulum, dan analisis karakteristik siswa

Tabel 1. Komponen RPP

\begin{tabular}{cl}
\hline No. & \multicolumn{1}{c}{ Komponen RPP } \\
\hline 1 & Identitas sekolah yaitu nama satuan \\
& pendidikan \\
2 & Identitas mata pelajaran atau tema/subtema \\
3 & Kelas/semester \\
4 & Materi pokok \\
5 & Alokasi waktu \\
6 & Tujuan pembelajaran \\
7 & Kompetensi dasar dan indikator pencapaian \\
& kompetensi \\
8 & Materi pembelajaran \\
9 & Metode pembelajaran \\
10 & Media pembelajaran \\
11 & Sumber belajar \\
12 & Langkah-langkah pembelajaran \\
13 & Penilaian hasil belajar \\
&
\end{tabular}

Langkah-langkah menyusun LKPD menurut Prastowo (2011) adalah sebagai berikut:

a. Menganalisis kurikulum

b. Menyusun peta kebutuhan LKPD

c. Menentukan judul LKPD

d. Penulisan LKPD

Menurut Mardapi (2012) teknik penyusunan tes ada Sembilan langkah dalam menyusun tes hasil belajar yang baku seperti berikut ini:

a. Menyusun spesifikasi tes, prosedur dalam penyusunan spesifikasi tes terdiri atas menentukan tujuan tes, menyusun kisi-kisi tes, menentukan bentuk tes dan menentukan panjang tes

b. Menulis tes, keterampilan dalam menulis tes yang baik sangat di perlukan agar dapat menghasilkan tes yang valid

c. Menelaah tes, kriteria yang digunakan untuk melakukan telaah butir tes mengikuti pedoman penyusunan tes. Telaah dilakukan terhadap kebenaran konsep, teknik penulisan dan Bahasa yang digunakan.

d. Melakukan ujicoba tes, sebelum soal digunakan dalam tes yang sesungguhnya, ujicoba perlu dilakukan untuk semakin memperbaiki kualitas soal.

e. Menganalisis tes, berdasarkan hasil ujicoba selanjutnya dilakukan analisis butir soal berdasarkan data empirik hasil ujicoba

f. Memperbaiki tes, setelah dianalisis selanjutnya dilakukan perbaikan-perbaikan tentang bagian soal yang masih belum sesuai dengan yang diharapkan.

g. Merakit tes, setelah diperbaiki tes dirakit menjadi satu kesatuan tes

h. Melakasanakan tes, tes yang telah disusun diberikan kepada testee untuk diselesaikan

i. Menafsirkan tes, hasil tes menghasilkan data kuantitatif yang berupa skor. Skor ini kemudian ditafsir sehingga menjadi nilai rendah, menengah dan tinggi.

\subsection{Tahap Pengembangan (Development)}

Tahap development adalah langkah ketiga dari model pengembangan ADDIE. Tahap ini merupakan tahap realisasi rancangan perangkat pembelajaran. Pada tahap ini, peneliti mulai membuat perangkat pembelajaran dengan model PBL yang sesuai dengan yang telah dirancang pada tahap perancangan. Pada tahap ini dikembangkan perangkat pembelajaran matematika dengan menggunakan model PBL pada materi SPLDV siswa SMP kelas VIII.

\section{Pengembangan RPP}

RPP yang dikembangkan mengacu pada komponen-komponen RPP seperti: Identitas sekolah, identitas mata pelajaran, kelas atau semester, materi pokok, alokasi waktu, tujuan pembelajaran, kompetensi inti, kompetensi dasar, indikator pencapaian kompetensi, materi pelajaran, metode pembelajaran, langkah-langkah pembelajaran, media pembelajaran, sumber belajar, dan penilaian hasil pembelajaran. Pada penelitian ini, Rencana Pelaksanaan Pembelajaran disusun sebanyak dua RPP yaitu RPP 1 dan RPP 2 . Masing-masing RPP tersebut dirancang untuk satu kali pertemuan.

\section{Pengembangan Lembar Kerja Peserta Didik}

LKPD yang dikembangkan dalam penelitian ini dibuat sebanyak 2 LKPD yaitu Lembar Kerja Peserta Didik 1 dan Lembar Kerja Peserta Didik 2. Pada masing-masing LKPD tersebut dirancang untuk satu kali pertemuan. Pengembangan Lembar Kerja Peserta Didik dilakukan sesuai dengan desain awal yang telah ditetapkan.

Hasil dari pengembangan Lembar Kerja Peserta Didik adalah Lembar Kerja Peserta Didik 
mata pelajaran matematika pada materi Sistem Persamaan Linear Dua Variabel dengan model pembelajaran Problem Based Learning untuk siswa SMP Katolik Sta. Rosa De Lima Tondano. Lembar Kerja Peserta Didik yang dikembangkan meliputi komponen-komponen yang memudahkan siswa dalam memahami materi yang diajarkan.

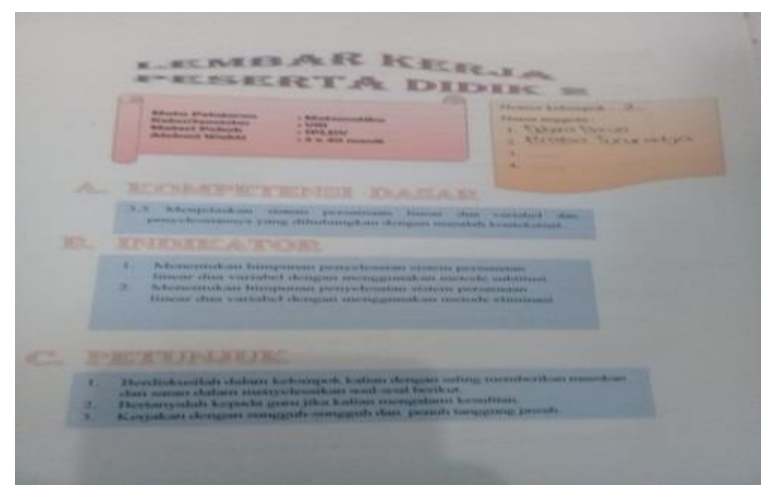

Gambar 1. Lembar kerja peserta didik

\section{Pengembangan Evaluasi Hasil Belajar}

Pada penelitian ini, Evaluasi Hasil Belajar dibuat sebanyak 2 Evaluasi Hasil Belajar yaitu Evaluasi Hasil Belajar 1, dan Evaluasi Hasil Belajar 2. Pengembangan Evaluasi Hasil Belajar dilakukan sesuai desain awal yang ditetapkan. Masing-masing Evaluasi Hasil Belajar tersebut dirancang untuk satu kali pertemuan.

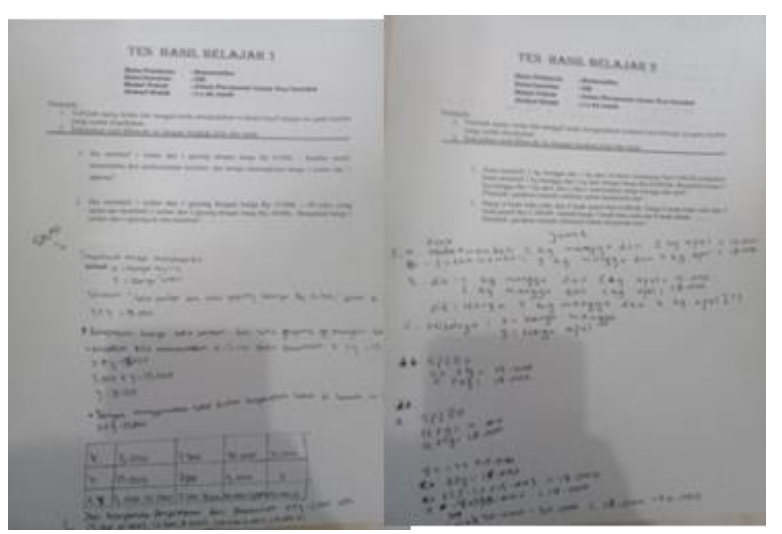

Gambar 2. Menyelesaikan Evaluasi Hasil Belajar

\section{Penilaian Ahli atau Validator}

Penilaian oleh ahli dilakukan untuk mengetahui kevalidan, kepraktisan dan keefektifan pembelajaran yang dikembangkan berupa RPP, LKPD, dan EHB yang telah disetujui oleh dosen pembimbing kemudian divalidasi oleh validator. Validasi ahli yaitu penilaian RPP, LKPD, dan EHB menggunakan instrument penilaian RPP, LKPD, dan EHB berupa angket untuk dosen ahli.

\section{Hasil Uji Coba Produk}

Uji coba termasuk dalam kegiatan implementasi yang dilakukan setelah perangkat pembelajaran dinyatakan layak diujicobakan dengan revisi oleh ahli. Data ini digunakan untuk mengetahui kualitas Rencana Pelaksanaan Pembelajaran, Lembar Kerja Peserta Didik, dan Evaluasi Hasil Belajar yang dikembangkan. Berikut ini akan diuraikan penjelasan mengenai data yang diperoleh dari hasil uji coba perangkat yang dikembangkan.

\section{Data Kepraktisan}

Data kepraktisan diperoleh dari hasil respon siswa, dan keterlaksanaan pembelajaran: (1) Data Penilaian Siswa: Data penilaian siswa diperoleh dari 10 siswa di kelas VIII SMP Katolik Sta. Rosa De Lima Tondano. Penilaian ini diperoleh setelah siswa melaksanakan pembelajaran matematika dengan menggunakan Lembar Kegiatan Peserta Didik dan Evaluasi Hasil Belajar yang dikembangkan, dan (2) Data Keterlaksanaan Pembelajaran: Selama pelaksanaan pembelajaran, dilakukan observasi untuk mengetahui keterlaksanaan langkah-langkah pembelajaran yang ada pada Rencana Pelaksanaan Pembelajaran yang dikembangkan. Data keefektifan diperoleh dari hasil tes belajar siswa yang dilakukan diakhir pembelajaran matematika.

\section{Revisi Produk}

Berdasarkan tahap yang telah dilakukan, diperoleh juga beberapa saran dianataranya 1) pembagian waktu pada langkah-lanhkah pembelajaran belum detail, 2) tidak mencantumkan foto atau video pada kegiatan mengamati, 3) tidak melampirkan instrument penilaian, mengenai perangkat pembelajaran yang dikembangkan. Peneliti melakukan evaluasi terhadap Rencana Pelaksanaan Pembelajaran (RPP), Lembar Kegiatan Peserta Didik, dan Evaluasi Hasil Belajar yang dikembangkan. Hal ini dilakukan untuk memperbaiki Rencana Pelaksanaan Pembelajaran, Lembar Kegiatan Peserta Didik, maupun Evaluasi Hasil Belajar yang ditemui peneliti selama melakukan uji coba.

\section{Revisi Rencana Pelaksanaan Pembelajaran}

Setelah melakukan penilaian dari ahli terhadap Rencana Pelaksanaan Pembelajaran yang dikembangkan, terdapat beberapa saran yang digunakan untuk merevisi RPP agar Rencana Pelaksanaan Pembelajaran yang dikembangkan layak digunakan dalam pembelajaran matematika dengan menggunakan model PBL. Revisi Rencana Pelaksanaan Pembelajaran menurut para ahli adalah sabagai berikut. (1) Pembagian waktu pada setiap kegiatan pembelajaran sudah detail, (2) Sudah mencantumkan foto atau video pada kegiatan mengamati, (3) Instrument penilaian sudah dilampirkan. 


\section{Revisi LKPD dan EHB}

Setelah melakukan penilaian dari ahli terhadap Lembar Kegiatan Peserta Didik dan Evaluasi Hasil Belajar yang dikembangkan, terdapat beberapa saran yang perlu direvisi yaitu dalam penulisan agar Lembar Kegiatan Peserta Didik dan Evaluasi Hasil Belajar yang dikembangkan layak digunakan dalam pembelajaran matematika.

\section{Kajian Produk Akhir}

Berdasarkan hasil penelitian yang telah diuraikan di atas, diperoleh produk berupa Rencana Pelaksanaan Pembelajaran (RPP), Lembar Kegiatan Peserta Didik (LKPD), dan Evaluasi Hasil Belajar (EHB) dengan model PBL yang valid, praktis, dan efektif. Langkah-langkah penyusunan dan pengembangan Rencana Pelaksanaan Pembelajaran (RPP) dan Lembar Kegiatan Peserta Didik (LKPD) tersebut dilakukan dengan model pengembangan ADDIE (Analisys, Design, Development, Implementation, Evaluation). Melakukan analisis yang meliputi:

a. Analisis kebutuhan: menganalisis kebutuhan untuk menetapkan masalah dasar yang dihadapi dalam pembelajaran matematika pada materi sistem persamaan linear dua variable

b. Analisis kurikulum: menganalisis materi pokok kelas VIII SMP Katolik Santa Rosa De Lima Tondano.

c. Analisis karakteristik siswa: menganalisis kondisi siswa di SMP Katolik Santa Rosa De Lima Tondano berdasarkan hasil wawancara dengan guru matematika SMP Katolik Sta. Rosa De Lima Tondano.

d. Perancangan Rencana Pelaksanaan Pembelajaran (RPP), Lembar Kegiatan Peserta Didik (LKPD), dan Evaluasi Hasil Belajar (EHB) yang meliputi:

e. Perancangan RPP, LKPD, dan EHB: RPP dibuat sebanyak dua RPP sesuai dengan standar proses, sedangkan LKPD dibuat berdasarkan aspek materi/isi, standar proses, syarat konstruksi, dan syarat teknis

f. Perancangan instrument penilaian yaitu peneliti menyusun instrumen penilaian bahan ajar sebagai alat untuk mengukur kelayakan RPP, LKPD, dan EHB yang dihasilkan.

g. Pengembangan Rencana Pelaksanaan Pembelajaran (RPP), Lembar Kegiatan Peserta Didik (LKPD), dan Evaluasi Hasil Belajar (EHB) yang meliputi:

1) Pengembangan instrument penelitian berupa lembar validasi yang diisi oleh dosen ahli, lembar penilaian kepraktisan yang diisi oleh guru dan siswa, lembar observasi pembelajaran yang diisi oleh observer untuk mengukur keefektifan produk.

2) Pengembangan Rencana Pelaksanaan Pembelajaran (RPP) sesuai desain pada tahap perancangan.

3) Pengembangan Lembar Kerja Peserta Didik (LKPD) dan Evaluasi Hasil Belajar (EHB) sesuai desain pada tahap perancangan.

4) Implementasi Rencana Pelaksanaan Pembelajaran (RPP) dan Lembar Kerja Peserta Didik (LKPD): dilakukan pada bulan Juni.Evaluasi terhadap Rencana Pelaksanaan Pembelajaran (RPP), Lembar Kegiatan Peserta Didik (LKPD), dan Evaluasi Hasil Belajar (EHB): RPP, LKPD, dan EHB dievaluasi terkait kevalidan, kepraktisan, dan keefektifannya.

\subsection{Tahap Implementasi (Implementation)}

\section{Uji Coba Perangkat}

Setelah perangkat pembelajaran dinyatakan layak oleh ahli, maka perangkat pembelajaran diimplementasikan yaitu dapat digunakan dalam kegiatan pembelajaran. Hasil uji coba akan dijadikan acuan untuk merevisi kembali perangkat pembelajaran yang dikembangkan. Uji coba produk dilaksanakan di SMP Katolik Sta. Rosa De Lima Tondano dengan subjek penelitian yaitu siswa kelas VIII.

Dalam implementasi pembelajaran, penggunaan perangkat pada kegiatan pembelajaran mereka bisa dikelompokan. Kelompok dipilih secara heterogen dan terdiri dari 2 orang. Kegiatan kelompok selain mengerjakan kegiatan diskusi, mereka juga melakukan aktifitas siswa secara bersama-sama dan berdiskusi apabila ada siswa dalam kelompok yang mengalami kesulitan.

Pada pembelajaran ini, terlihat bahwa siswa tertarik dan termotivasi untuk menyelesaikan masalah yang ada pada LKPD dan EHB. Hal ini dapat dilihat ketika siswa mengalami kesulitan dalam menyelesaikan masalah yang sedang mereka hadapi. 


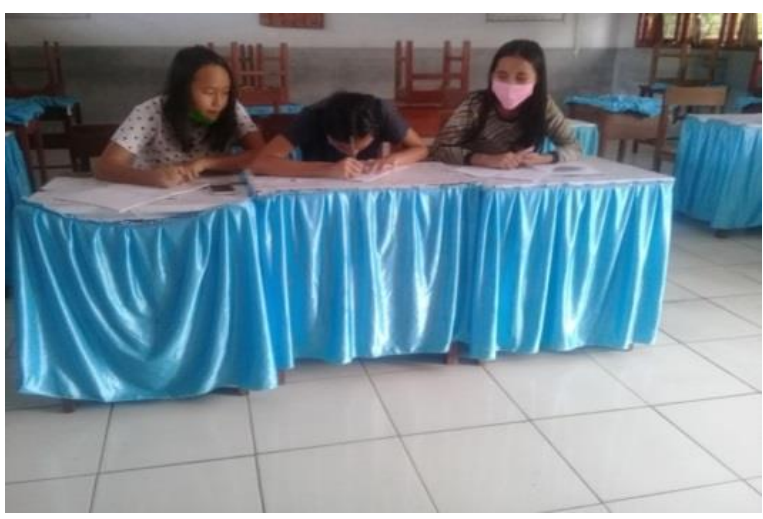

Gambar 3. Menyelesaikan LKPD

Setelah siswa memperoleh kesimpulan dan menuliskannya pada lembar jawaban, guru memberikan penguatan pada kesimpulan yang telah diperoleh siswa dengan terlebih dahulu meminta salah satu siswa mengungkapkan hasil kesimpulan yang telah mereka dapatkan. Dengan kesimpulan yang telah dikuatkan oleh guru, siswa dapat lebih memahami materi yang sedang mereka pelajari.

\section{Revisi Produk}

Produk yang telah selesai diujicobakan kemudian direvisi kembali berdasarkan masukan atau saran dari angket respon siswa setelah menggunakan produk pembelajaran yang telah dikembangkan

\subsection{Tahap Evaluasi (Evaluation)}

Evaluasi dilakukan dengan menganalisis data hasil penelitian yang diperoleh peneliti yaitu analisis kevalidan perangkat dari dosen ahli dan guru Data respon siswa terhadap kegiatan pembelajaran untuk mengetahui respon atau tanggapan siswa terhadap perangkat pembelajaran yang dikembangkan.

Melalui hasil pengisian angket respon siswa akan diketahui apakah LKPD yang dikembangkan masuk dalam kategori praktis. Analisis keefektifan perangkat pembelajaran dapat di peroleh dari evaluasi hasil belajar.

\section{Analisis Data dan Pembahasan}

Analisis data dan hasil ujicoba yang dimaksudkan adalah respon siswa terhadap kegiatan pembelajaran dan tes hasil belajar. Analisis data hasil ujicoba perangkat pembelajaran sistem persamaan linear dua variabel yang dikembangkan antara lain analisis kevalidan, analisis kepraktisan, dan analisis keefektifan perangkat pembelajaran.

Analisis Kevalidan Perangkat Pembelajaran Rencana Pelaksanaan Pembelajaran
Setelah dilakukan proses validasi oleh validator, dapat dilihat bahwa lima orang validator memberikan penilaian $3 \mathrm{ke}$ atas dengan rata-rata, berarti komponen-komponen dalam RPP mendapatkan penilaian baik dan sangat baik dan dapat digunakan dengan sedikit revisi pada RPP.

Tabel 2. Hasil Validasi RPP

\begin{tabular}{lllllll}
\hline No & $\begin{array}{c}\text { Aspek } \\
\text { dinilai }\end{array}$ & yang & $\begin{array}{l}\text { Nilai yang } \\
\text { validator }\end{array}$ & diberikan \\
\cline { 3 - 6 } & 1 & 2 & 3 & 4 & 5
\end{tabular}

1

\section{Format RPP}

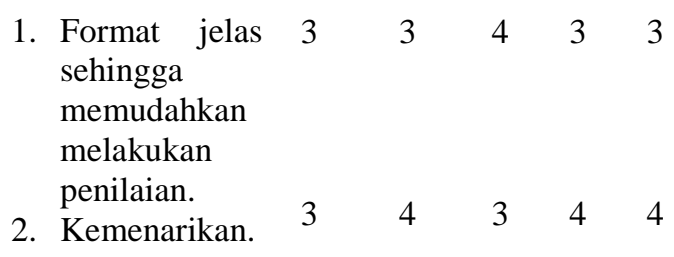

\section{Isi RPP}

1. Kompetensi

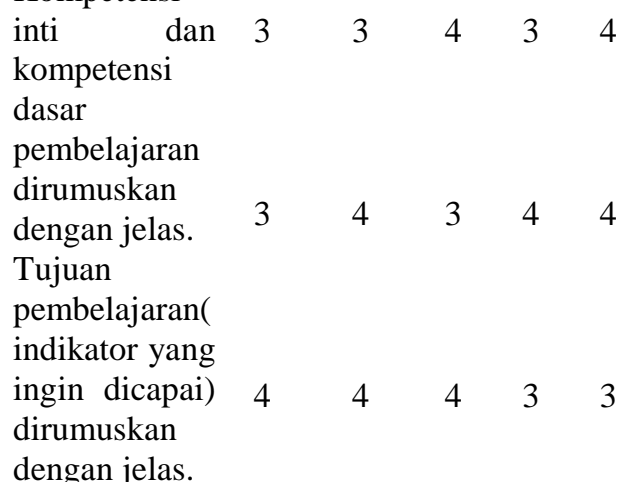

3. Menggambark

an kesesuaian metode pembelajaran dengan langkahlangkah pembelajaran yang dilakukan.

4. Langkahlangkah pembelajaran dirumuskan dengan jelas dan mudah dipahami.

\section{Bahasa dan}

\section{Tulisan:}

\begin{tabular}{llllll} 
1. $\begin{array}{l}\text { Menggunaka } \\
\text { n bahasa yang } \\
\text { sesuai dengan } \\
\text { kaidah bahasa }\end{array}$ & 3 & 3 & 4 & 4 & 3 \\
$\begin{array}{l}\text { Indonesia } \\
\text { yang baku. }\end{array}$ & 3 & 3 & 4 & 4 & 4 \\
\hline
\end{tabular}






Setelah dilakukan proses validasi oleh validator, dapat dilihat bahwa lima orang validator memberikan penilaian 3 ke atas dengan rata-rata 3,6. Dibandingkan dengan kriteria kevalidan maka $3,5 \leq 3,6<4$, berarti komponen-komponen dalam RPP mendapatkan penilaian baik dan sangat baik dan dapat digunakan dengan sedikit revisi pada RPP.

\section{Lembar Kerja Peserta Didik}

Setelah dilakukan proses validasi oleh validator, dapat dilihat bahwa tiga validator memberikan penilaian 3 ke atas, berarti komponenkomponen dalam LKPD mendapatkan penilaian baik dan sangat baik dan dapat digunakan.

Tabel 3. Hasil Validasi LKPD

\begin{tabular}{lllllll}
\hline No & $\begin{array}{l}\text { Aspek yang } \\
\text { dinilai }\end{array}$ & $\begin{array}{l}\text { Nilai } \\
\text { validator }\end{array}$ & yang & diberikan \\
\cline { 2 - 6 } 1 & 1 & 2 & 3 & 4 & 5 \\
& $\begin{array}{l}\text { Format } \\
\text { LKPD } \\
1 . \quad \begin{array}{l}\text { Kejelasan } \\
\text { pembagia } \\
\text { n materi } \\
\text { Kemenari } \\
\text { kan }\end{array}\end{array}$ & 3 & 3 & 4 & 4 & 3 \\
& & 4 & 3 & & 3 \\
\hline
\end{tabular}

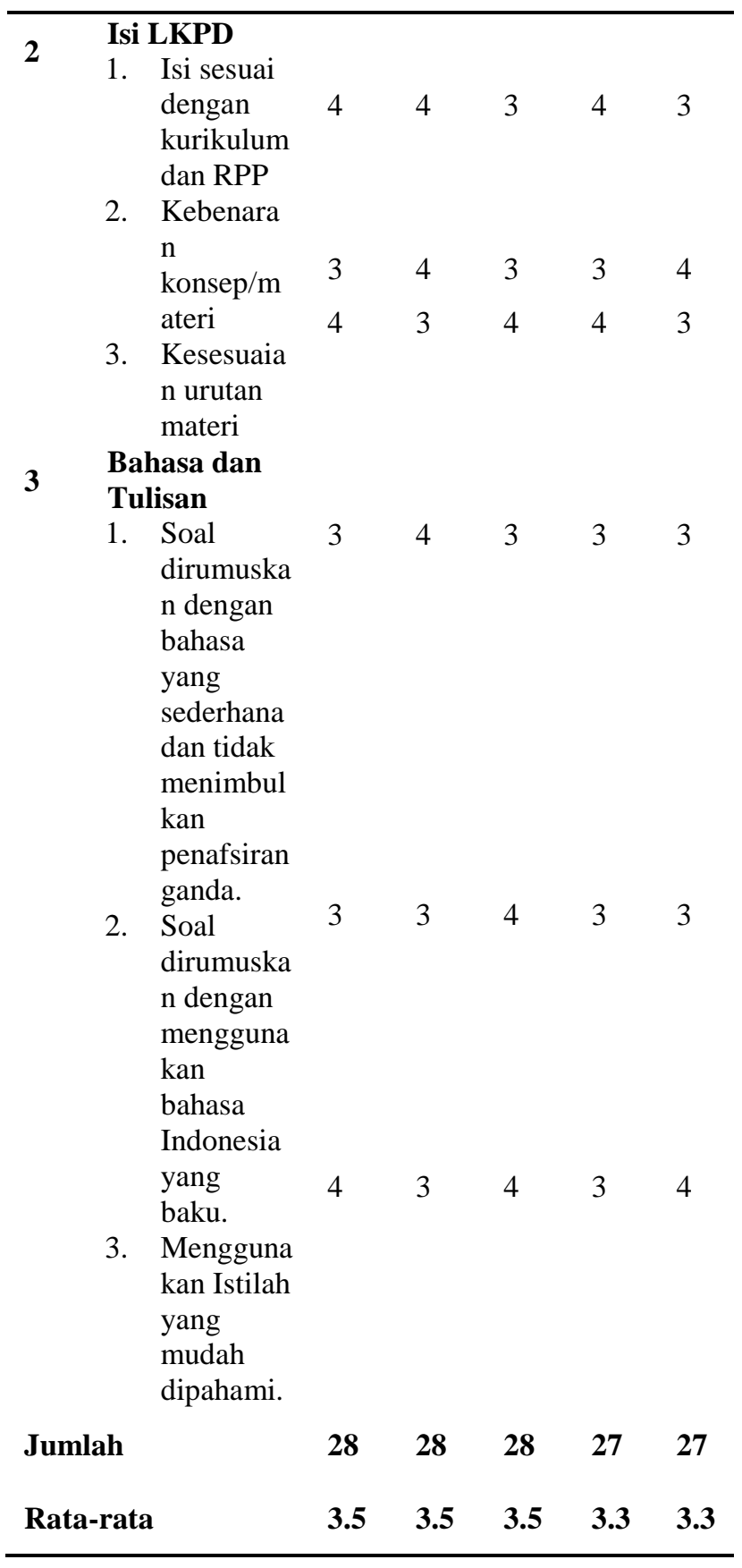

Setelah dilakukan proses validasi oleh validator, dapat dilihat bahwa lima validator memberikan penilaian 3 ke atas dengan rata-rata 3,4 . Jika di bandingkan dengan kriteria kevalidan maka $2,5 \leq 3,4<3,5$ berada pada kategori valid, sehingga komponen-komponen dalam LKPD mendapatkan penilaian baik dan sangat baik dan dapat digunakan dengan sedikit revisi.

\section{Evaluasi Hasil Belajar}

Kelima validator memberikan penilaian baik sehingga memenuhi kriteria valid untuk validitas isi, sangat dapat dipahami untuk bahasa dan penulisan soal, serta dapat digunakan dengan tanpa sedikit revisi. 
Tabel 4. Hasil Validasi EHB

\begin{tabular}{|c|c|c|c|c|c|c|c|c|}
\hline $\begin{array}{l}\text { Butir } \\
\text { Soal }\end{array}$ & \multicolumn{5}{|c|}{ Validitas Isi } & \multicolumn{3}{|c|}{$\begin{array}{l}\text { Bahasa dan } \\
\text { Penulisan Soal }\end{array}$} \\
\hline & $\mathrm{V}$ & $\mathrm{C}$ & K & TV & SD & $\mathrm{DP}$ & $\mathrm{K}$ & TD \\
\hline & & $\mathrm{V}$ & V & & $\mathrm{P}$ & & DP & $\mathrm{P}$ \\
\hline 1 & 2 & & & & 2 & & & \\
\hline 2 & 1 & 1 & & & 1 & 1 & & \\
\hline 3 & 2 & & & & 2 & & & \\
\hline 4 & 1 & & 1 & & 1 & & & \\
\hline \multirow[t]{4}{*}{5} & 2 & & & & 2 & & & \\
\hline & 10 & 1 & 1 & 0 & 10 & 1 & 0 & 0 \\
\hline & 50 & 1 & 1 & 0 & 50 & & 0 & 0 \\
\hline & & & & & & & & \\
\hline $\begin{array}{c}\text { Rata- } \\
\text { rata }\end{array}$ & & & & & & & & \\
\hline $\begin{array}{c}\text { Rata- } \\
\text { rata } \\
\text { total }\end{array}$ & \multicolumn{8}{|c|}{4,68} \\
\hline
\end{tabular}

Berdasarkan tabel penilaian di atas dapat dilihat rata-rata total skor validasi EHB adalah 4,68. Di bandingkan dengan kriteria kevalidan maka $4 \leq 4,68 \leq 5$.

Kelima validator memberikan penilaian baik sehingga memenuhi kriteria sangat valid untuk validitas isi, sangat dapat dipahami untuk bahasa dan penulisan soal, serta dapat digunakan dengan tanpa sedikit revisi.

\section{Analisis Angket Respon Siswa}

Berdasarkan data dari angket respon siswa yang telah diisi oleh 10 siswa setelah mengikuti kegiatan pembelajaran untuk materi SPLDV dengan model Problem Based Learning maka diperoleh hasil sebagai berikut.

Misalnya Apakah kamu berminat mengikuti kegiatan belajar berikutnya seperti yang telah kamu ikuti sekarang ini? dan jawabannya berminat semua, Bahasa yang digunakan dalam LPKD dan EHB semuanya menjawab baik, dan Penampilan (tulisan, gambar, letak gambar) yang terdapat pada LKPD dan EHB juga menjawab baik semuanya.

\section{Analisis Kemampuan Guru Mengelola Pembelajaran}

Berdasarkan kriteria kemampuan guru yang telah diuraikan kemampuan guru mengelola pembelajaran pada pertemuan pertama sampai kedua mencapai kategori "Baik", yaitu terletak pada interval 3,50 $\leq \mathrm{TKG}<4,50$.

Dengan demikian Kemampuan Guru Mengelola Pembelajaran sudah mencapai kategori baik, maka perangkat pembelajaran ini tidak mengalami revisi berdasarkan hasil pengamatan kemampuan mengelola pembelajaran.

\section{Analisis Keefektifan Perangkat Pembelajaran}

Ketuntasan belajar adalah 10 siswa adalah $80 \%$. Berdasarkan kriteria penilaian, maka dapat dikatakan bahwa perangkat yang dikembangkan memenuhi kategori efektif.

\section{Analisis Data Evaluasi Hasil Belajar}

Ujicoba tes hasil belajar bertujuan untuk mendapatkan data tentang validitas butir tes yang akan menentukan apakah tes yang dikembangkan perlu direvisi atau tidak dan dinyatakan bahwa semua butir tes tersebut dikatakan valid.

Berdasarkan hasil perhitungan diperoleh koefisien reliabilitas $=0,6118$. Dari hasil yang diperoleh, reliabilitas instrument Tes Hasil Belajar yang dikembangkan termasuk pada kategori "tinggi" dan dapat dikatakan reliabel.

Berdasarkan uraian sebelumnya, bahwa perangkat pembelajaran yang telah dikembangkan valid berdasarkan validasi ahli, dikatakan praktis berdasarkan hasil kemampuan guru mengelola pembelajaran di kelas dan respon siswa terhadap kegiatan pembelajaran, serta efektif berdasarkan hasil belajar secara klasikal.

Dengan demikian, maka telah dikembangkan perangkat pembelajaran sistem persamaan linear dua variabel dengan model pembelajaran PBL di kelas VIII SMP Katolik Sta. Rosa De Lima Tondano.

\section{Kesimpulan}

Penelitian pengembangan yang dilaksanakan di SMP Katolik Santa Rosa De Lima Tondano dengan subyek penelitian adalah siswa kelas VIII tahun pelajaran 2019/2020 telah menghasilkan perangkat pembelajaran yang valid, praktis, dan efektif.

Setelah diujicobakan dan telah melalui proses validasi isi. Perangkat yang dikembangkan adalah Rencana Pelaksanaan Pembelajaran, Lembar Kerja Peserta Didik, Evaluasi Hasil Belajar dengan model PBL pada materi SPLDV.

Perangkat pembelajaran yang divalidasi menghasilkan perangkat dengan kriteria valid. Dari segi kepraktisan maka perangkat pembelajaran berada pada kategori sangat praktis sesuai dengan tanggapan atau respon siswa. Perangkat pembelajaran efektif ditinjau dari TKG yang berada pada kategori sangat baik dan persentase ketuntasan klasikal berada pada klasifikasi sangat baik. 


\section{Daftar Pustaka}

Endang Mulyatiningsih. (2013). Metode Penelitian Terapan Bidang Pendidikan. Bandung: Alfabeta. Mardapi Djemari, 2012. Pengukuran Penilaian \& Evaluasi Pendidikan. Yogyakarta: Nuha Medika. Mulyasa, E. 2005. Menjadi Guru Profesional. Bandung: PT. Remaja Rosda Karya

Nieveen, N. (1999). "Prototype to reach product quality. Dlm. van den Akker, J., Branch, R.M., Gustafson, K., Nieveen, N., \& Plomp, T. (pnyt.)". Design approaches and tools in educational and training. Dordrecht: Kluwer Academic Publisher.
Permendikbud Nomor 20 Tahun 2016 tentang Standar Kompetensi Lulusan Pendidikan Dasar Dan Menengah.

Permendikbud Nomor 23 Tahun 2016 Tentang Standar Penilaian Pendididkan.

Slameto. (2013). Belajar dan Faktor-Faktor yang Mempengaruhinya. Jakarta: PT Rineka Cipta.

Soemanto, Wasty. (2006). Psikologi Pendidikan: Landasan Kerja Pemimpin Pendidikan (Cetakan Ke 5). Jakarta: Rineka Cipta.

Trianto. (2009). Mendesain Model Pembelajaran Inovatif Progresif.Surabaya: Kencana

Trianto. (2010). Model Pembelajaran Terpadu. Jakarta: Bumi Aksara

Trianto. (2012). Model Pembelajaran Terpadu. Jakarta: Bumi Aksara. 